\title{
Pre-industrial human and environment interactions in northern Peru during the late Holocene
}

\author{
Tom Dillehay ${ }^{*}$, Alan L. Kolata ${ }^{2}$ and Mario Pino Q. ${ }^{3}$
}

$\left({ }^{1}\right.$ Department of Anthropology, University of Kentucky, Lexington 40506, USA; ${ }^{2}$ Department of Anthropology, University of Chicago, Chicago, Illinois 60637, USA; ${ }^{3}$ Instituto de Geociencias, Universidad Austral de Chile, Chile)

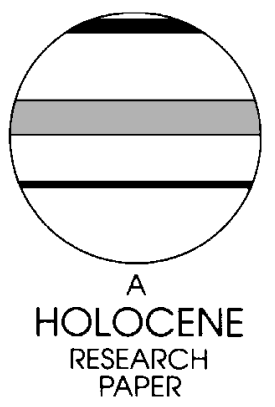

\section{Introduction}

Throughout history climate anomalies have disrupted normal weather patterns and forced significant behavioural changes in human populations. Abrupt-impact events such as catastrophic droughts, earthquakes and floods, as well as long-term environmental changes, can exert great stress on societies that, in turn, induces significant adaptations in economic, political and social organization (Fagan, 1999; Bawden and Reycraft, 2000; Weiss and Bradley, 2001; Hoffman and Oliver-Smith, 2002). Little is known in the archaeological record, however, about the specific social and economic responses of societies adapting to environmental stress in the past, especially with respect to harsh, often fragile environments such as the desert coast of Peru. Understanding these issues in Peru is important because it is one of the few

*Author for correspondence (e-mail: dilleha@uky.edu) areas in the world where pre-industrial states and urbanism developed independently despite a long history of intermittent environmental catastrophes. Between $250 \mathrm{BC}$ and $\mathrm{AD} 1450$, the north coast saw the emergence of three powerful urban societies, the Moche, Lambayeque and Chimu, that were characterized by elaborate symbolic systems, massive cities and élite residences, numerous rural villages, and large-scale irrigation and road networks. How these societies adapted and specifically responded to severe environmental crisis are the subjects of this study.

Human populations and the physical environment interact through dynamic ecological processes. This interaction operates constantly, changing environmental constraints and creating new challenges and opportunities for the reproduction of the biological and cultural bases of human society. In pre-industrial societies the two social processes with the greatest potential impact on changing human-environment relations are urbanization and the development of diversified, regional-scale production systems such as 
intensive agriculture, pastoralism and the exploitation of marine resources. Potential human responses to environmental crises are population aggregation or dispersal, changes in economic strategies and social organization, increase in the incidence of conflict and warfare and, in some instances, even urban abandonment and political collapse (e.g., Yoffee and Cowgill, 1988; Tainter, 1989; Kolata, 1993a; 1993b; Bawden and Reycraft, 2000; Weiss and Bradley, 2001). These responses are not site-specific and independent. Rather they operate at the interlocal scale of the regional landscape and are conceptually and instrumentally interlinked (Crumley and Marquardt, 1990; Rossignol and Wandsnider, 1992).

Urbanization and intensive agricultural production generate substantial environmental change across cultural landscapes, principally by stimulating rapid increase in individual and collective consumption of both renewable and non-renewable resources. That is, urbanization creates new patterns of economic exploitation, transforms pre-existing land-use patterns, often depletes local and non-local resources and, inevitably, contaminates the physical environment. Further, the environmental impact of urbanization cannot be disentangled from social processes within city systems, such as changing patterns of economic growth, recession and decline, fluctuations in the consumption needs of growing human populations (Kolata, 2002), or abandonment and reuse of strategically located rural settlements (Dillehay, 2001).

At the same time, both abrupt and long-term changes in the physical environment can have a substantial impact on the viability of urban and rural life, especially in fragile, risk-prone desert landscapes such as coastal Peru. The most prominent impacts in this region were produced by catastrophic flooding generated by periodic ENSO (El Niño) events (Craig and Shimada, 1986; Moseley et al., 1992; Uceda and Amico, 1993; Bawden and Reycraft, 2000), local and regional droughts (Shimada, 1990; 1994; Shimada et al., 1991), desertification in the form of protracted dune migration and consequent sand inundation of human settlements, irrigation canals and agricultural lands (Eling, 1981; 1987), and tectonic and seismic activity generating a loss or depletion of natural resources (Moseley et al., 1992). Of course, not every impact had solely deleterious effects. For example, El Niño flooding is catastrophic for coastal agricultural production in the short term, but when floods recede they often deposit rich alluvium and recharge local groundwater.

Any attempt to understand human history in the desert coast of Peru must consider the recurrence and differential impact of major environmental changes on the cultural landscape. In 1997, we began an interdisciplinary research project in the lower Jequetepeque Valley (Figure 1) to study how urbanization and economic diversification developed within the complex physical environment of the north coast (Butterworth and Chance, 1981; King,

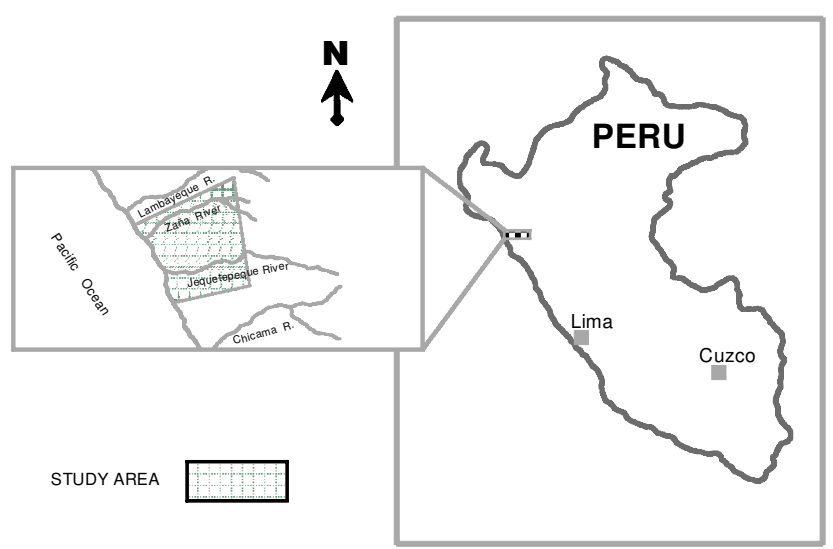

Figure 1 General location map of study area in the lower Jequetepeque Valley, Peru.
1990; Morse, 1962). Seven seasons of field research have focused on: (1) reconstructing the long-term environmental history of the valley through geomorphological and palaeolimnological methods, with a specific emphasis on El Niño, drought and dunation events; (2) documenting the spatial and temporal dynamics of large-scale agricultural systems in the valley through survey, mapping and excavations; and (3) analysing the social interactions of rural settlements with large-scale Late Moche and/or Chimu settlements (Figures 2 and 3). We discuss below our archaeological and geological evidence for these events and how urban and rural populations responded to them.

\section{Research design, environmental setting and culture history}

We addressed long-term human and environmental interaction on the north coast by developing an integrated, multiphase research programme. The strategy consisted of a first phase of fullcoverage archaeological survey of the lower Jequetepeque Valley between 1997 and 2002. A second phase (1998-2003) entailed test excavations in selected archaeological and geological sites to document chronology, stratigraphy, climatic change, diet and economy. The third, ongoing, phase includes extensive excavations in selected domestic contexts. We also have carried out geomorphological and palaeolimnological research to correlate the environmental history of the valley that relates to cultural events and processes.

The occupational longevity, cultural prominence and ecological setting of the Jequetepeque Valley, together with its extraordinary site preservation, offer an exceptional venue to explore human responses to environmental stress. Despite the extreme aridity and periodic, catastrophic flooding characteristic of the desert coast, the valley provided access to a broad spectrum of natural resources in prehispanic times (Kosok, 1965). Fertile agricultural land was abundant in the valley floor and on irrigable desert plains (Figure 1). The climate on the coastal plain is dry and warm. According to instrumental records over a 20 -year period, the mean temperature was $23.5^{\circ} \mathrm{C}$, with an absolute maximum of $37.5^{\circ} \mathrm{C}$ and an absolute minimum of $8.5^{\circ} \mathrm{C}$ (Eling, 1987: 104). Mean annual precipitation is $23 \mathrm{~mm} \mathrm{yr}^{-1}$. River discharge is highly variable and directly dependent upon precipitation in the adjacent highland watershed of the Cajamarca basin. In this respect, as along the coast in general, the hydrological regimes of the Jequetepeque Valley and its adjacent highland regions are linked. Evapotranspiration in the upper valley averages nearly $2000 \mathrm{~mm} \mathrm{yr}^{-1}$ (Salzgitter Industriebau GMBH, 1968: 45).

In the late prehispanic period, the Jequetepeque Valley contained approximately 88000 hectares of irrigated land, half of which is currently abandoned (Eling, 1981; 1987; Hecker and Hecker, 1982; 1991). The riparian environment, coastal lagoons and ocean littoral were rich breeding grounds for fish, shellfish and other aquatic resources. Today, most of the alluvial floodplain is planted in sugar cane, corn and rice with less productive upland soils abandoned. Small fishing communities persist along the coast. Similarly, the geological characteristics of the valley yielded economically important inorganic resources: porphyritic basalts for groundstone utensils and construction materials and high-quality clays for ceramic production. The strategic location of several large urban sites (e.g., Pacatnamu, San Jose de Moro, Cañoncillo, Talambo and Farfan) on two natural corridors, one extending north-south along the littoral zone and the other eastwest inland into the intermontane basins of the Andean chain, facilitated the distribution of these diverse products (Figure 1).

Physical constraints to human exploitation of natural resources on the north coast were imposed seasonally, periodically or permanently by a variety of environmental factors: annual river 


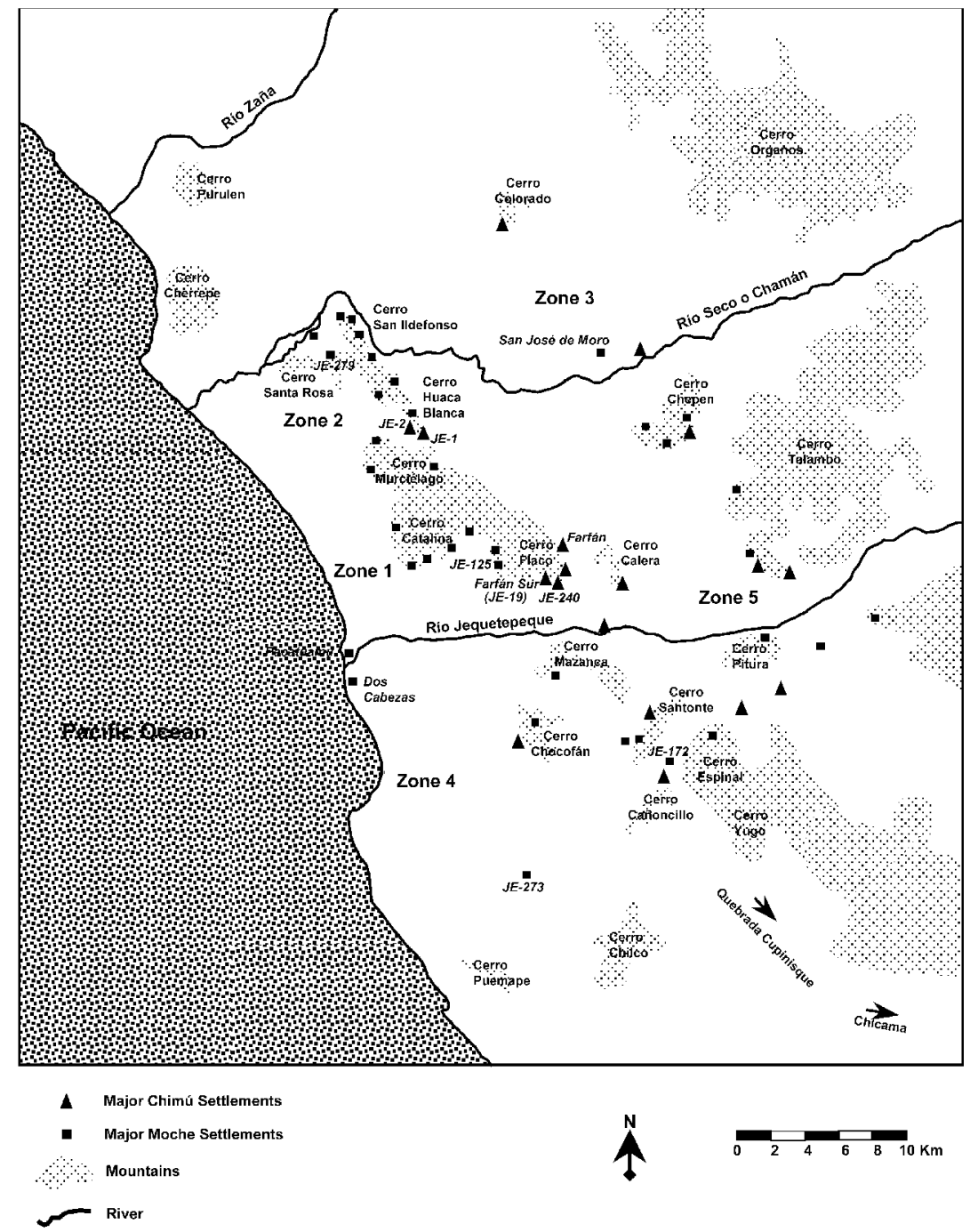

Figure 2 Location map of the major topographic features and Late Moche and Chimu sites in the study area.

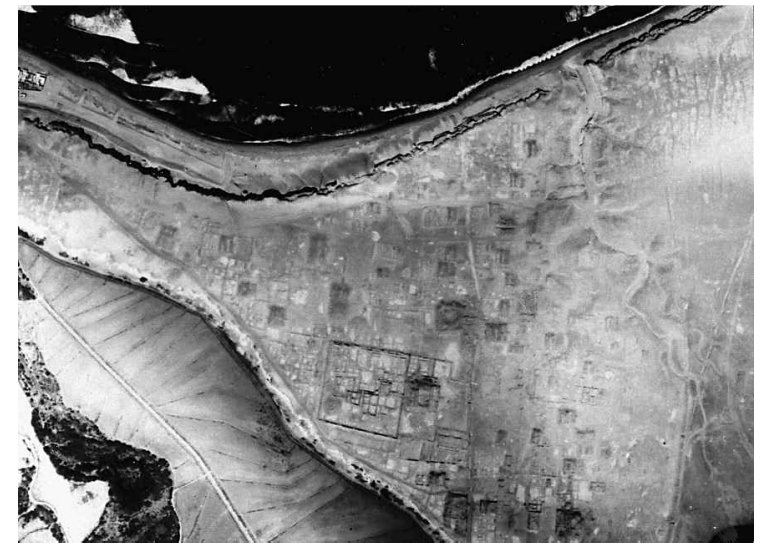

Figure 3 Large Moche, Lambayeque and Chimu site of Pacatnamu in zone 1 .

discharge, ENSO events, climatic fluctuation, dunation, desertification and massive landscape modification (e.g., Hsu et al., 1989; Philander, 1989; Diaz and Markgraf, 1992; Eling, 1987). Environmental perturbations of this sort, however, did not invariably limit the development of interlinked urban-rural systems in this desert environment. Cultural responses to these constraints in the form of periodic abandonment and reuse of sites, as well as innovation in technologies, political organization and economic strategies permitted intensification of production systems, as implied, for example, by an increase in the number
Table 1 Chronology of cultural periods on the north coast of Peru (adapted from Shimada, 1995: 4)

\begin{tabular}{lll}
\hline Timescale & Cultural periods & Zana-Jequetepeque Valley \\
\hline AD 1500 & Inca & Inca $(\sim 1470-1532)$ \\
AD 1300 & & \\
AD 1100 & Chimu & Chimu $(\sim 1100-1470)$ \\
AD 900 & Sican (Lambayeque) & Transitional $(\sim 800-1100)$ \\
AD 700 & & Late Moche Phase $(\sim 500-800)$ \\
AD 500 & & Middle Moche $(\sim 350-500)$ \\
AD 300 & Moche & Early Moche $(\sim 200-350)$ \\
AD 100 & & \\
100 BC & Gallinazo & \\
300 BC & Salinar & Salinar \\
500 BC & & \\
700 BC & Cupisnique & Cupisnique \\
\hline
\end{tabular}

of large urban settlements (e.g., Farfan, Cañoncillo, Pacatnamu and San Jose de Moro) in the lower Jequetepeque Valley from the Early Intermediate to the Late Intermediate periods (see Table 1) between approximately AD 250 and 1450 (Keatinge and Conrad, 1982; Schaedel, personal communication, 2000). This expansion within a complex matrix of environmental change must have entailed direct decision-making regarding population and resource concentration, the restructuring of urban-rural relations, extravalley alliances and other political and cultural factors.

In studying these issues, we divided the valley into four areas: 
(1) the desert plains between the mouth of the Jequetepeque and Seco (Chaman) rivers; (2) the basin between the Santa Catalina and Huaca Blanca mountain ranges; (3) the eastern flanks and desert plains of the Huaca Blanca, Murcielago and Faclo mountains; and (4) the south side of the lower Jequetepeque valley from the river to Cerro Chilco and Cañoncillo (Figure 2). To date, $100 \%$ survey coverage has recorded more than 950 new sites and 150 previously recorded sites, including residential occupations of different scales, agricultural fields, canals and water management systems, fortresses, isolated cemeteries and large, urban settlements. Distinct geomorphological features, including dune formations, yardangs (Eling, 1987), dry stream beds and inactive springs were also studied and associated with archaeological sites. Settlement information demonstrates occupation primarily in the Late Moche, Late Lambayeque and Chimu periods, with scattered earlier Moche sites.

Correlating periodic, abrupt and long-term environmental change with specific cultural developments is a difficult issue that we have addressed. Radiocarbon dates obtained by other projects in the region (Donnan and Cock, 1986; Castillo, 1994; 2001; Hecker et al., 1985: Keatinge, 1977; 1978; 1982; Conrad, 1990) coupled with 30 dates that we processed from 20 sites have resolved several issues of the chronology, synchronicity and potential cause/effect linkages between major environmental events and Late Moche, Lambayeque and Chimu cultural developments. ENSO, drought and other climate events have also been recorded in independent palaeoenvironmental records from lakes, ice cores (Thompson et al., 1985; Shimada et al., 1991) and active springs (Moseley et al., 1992). For instance, the Late Moche period (c. AD 550-650) at Pacatnamu was marked by El Niño flooding (Donnan and Cock, 1986; 1997) that may have destabilized its political economy and damaged its stature as an important ceremonial centre. This same El Niño event is registered at Late Moche sites outside the Jequetepeque Valley, including Pampa Grande (c. AD 500-600) in the Lambayeque Valley (Shimada, 1994) to the north and Galindo in the Moche Valley (Bawden, 1996 ) to the south. A later episode of massive flooding (AD 11001200) is documented by the presence of thick outwash deposits at the sites of Batan Grande and Huaca Chotuna also in the Lambayeque Valley (Shimada, 1994: 262).

Periods of extreme aridity are suggested at several Moche, Lambayeque and Chimu localities on the north coast by extensive deposits of aeolian sand and abandonment of large irrigation canals (Moseley, 1990; 1992). Stratigraphic records from several sites we have excavated in the Jequetepeque Valley and neighbouring Zana Valley to the north (Dillehay, 2001) also indicate sequential abandonment and reuse of sites and agricultural features (Figure 4) during the Late Moche and Lambayeque periods (AD 650-1100), which we attribute mainly to periodic droughts and floods. Territorial expansion and subsequent abandonment of several Chimu cities between AD 1350 and 1500, including Pacatnamu, San Jose de Moro, Cañoncillo, Talambo and Farfan, eventually occurred. What triggered these changes is not yet well understood. They may have been accelerated by environmental stress and/or by political realignments, urban collapse and rural reorganization of production systems, the latter of which is partly attributed to the Inca conquest of the region in the late AD 1400s. Major flooding and its devastating impact on regional populations is also recorded in historic records, such as a large flood in the lower Zana Valley around AD 1650 (cf. Nials et al., 1979). These findings, coupled with our ongoing research on soil characterization, staple isotopes, pollen and coring of highland lakes in the adjacent Cajamarca highland basin (M. Binford and M. Brenner, personal communication, 2000), will eventually provide additional interdisciplinary evidence on regional climatic change and on specific environmental impacts on different cultural and physical landscapes.

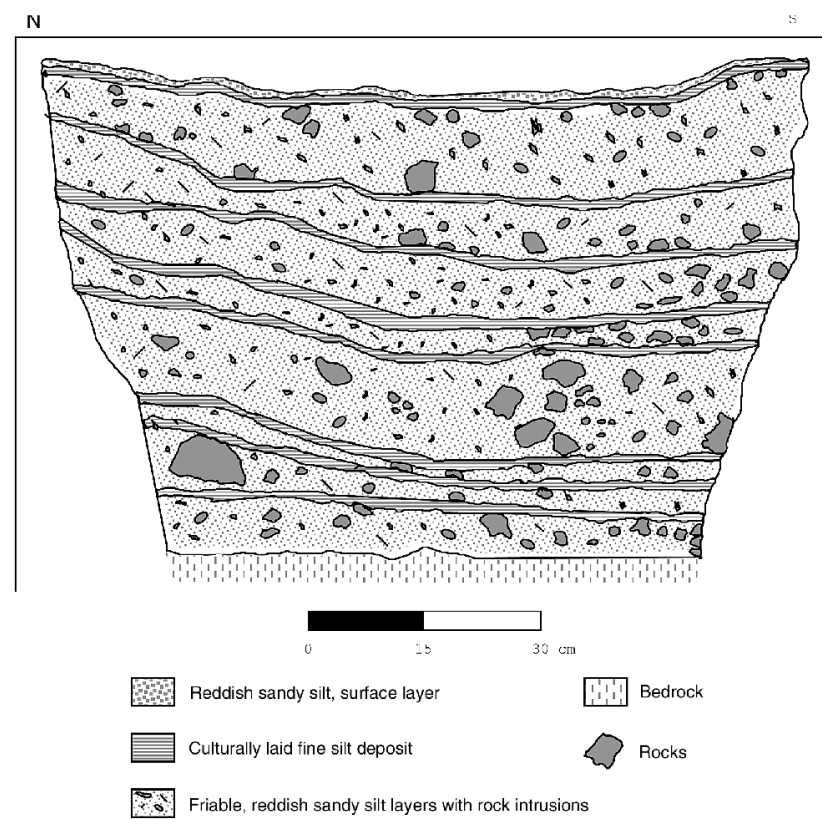

Figure 4 Stratigraphic profile of irrigation canal at JE-1, a Late Moche site radiocarbon dated at AD 750-850, showing intermittent use (fine silt deposited by slow moving irrigation water) and abandonment-rebuilding cycles (friable sandy silt with rock inclusions deposited by colluvial deposition from nearby hillside and by windblown sand).

\section{Documenting major environmental events and their impacts on the cultural landscape}

To date, our interdisciplinary study has examined more than 100 cross-sections in gullies and 80 excavated profiles in archaeological sites. Intermittent debris-flow and fine-grained aeolian deposits characterize the profiles of most gullies. In several gullies thin sheet flow deposits (1-3 mm thick) of low-energy sedimentation probably associated with normal precipitation and runoff are observed. There also is clear evidence for erosional truncation of many gully walls by periodic vertical aggradation and channel cutting and widening indicative of high energy debris-flow events. These erosional outwash events are characterized by 30 to $90 \mathrm{~cm}$ thick, graded debris-flow layers of unconsolidated coarse-grain sediment and rock fragments (Figure 5) that suggests rapid aggradation and water-level fluctuations most likely associated with ENSO events (M. Pino, personal communications, 1998 and 2001). We also documented sediment release signatures of slackwater flood deposits forming graded beds $30-85 \mathrm{~cm}$ thick in several natural drainage cuts in archaeological sites throughout the lower valley (M. Pino, personal communication, 1998), but particularly at Cañoncillo and at several localities on the desert plains between Pacatnamu and Farfan where dissected, steep topography facilitated rapid discharge. These deposits often contained Late Moche and Chimu ceramics indicative of high-magnitude outwash events that radiocarbon date to AD 415-650, 560-780, 1185-1295, 1180-1420 and 1640-1950 (Table 2).

Stratigraphic evidence in the non-élite domestic structures and élite platform mounds of many Late Moche and fewer Lambayeque and Chimu settlements also reveal erosional truncation of floors and features. These erosional events are clearly caused by high-energy debris-flows. Although ENSO-driven rains probably did not persist for long periods in any one locality, stratigraphic evidence in the Chimu sites of Farfan Sur (JE-19, zone 2), Cañoncillo (JE-172, zone 4) and Talambo (zone 4) and in several small $(<1 \mathrm{ha})$ to intermediate scale (c. 1-5 ha) residential sites in all zones exhibit thick $(20-80 \mathrm{~cm})$ deposits of fine-grained, graded silt and fragments of adobe walls that abruptly and severely 


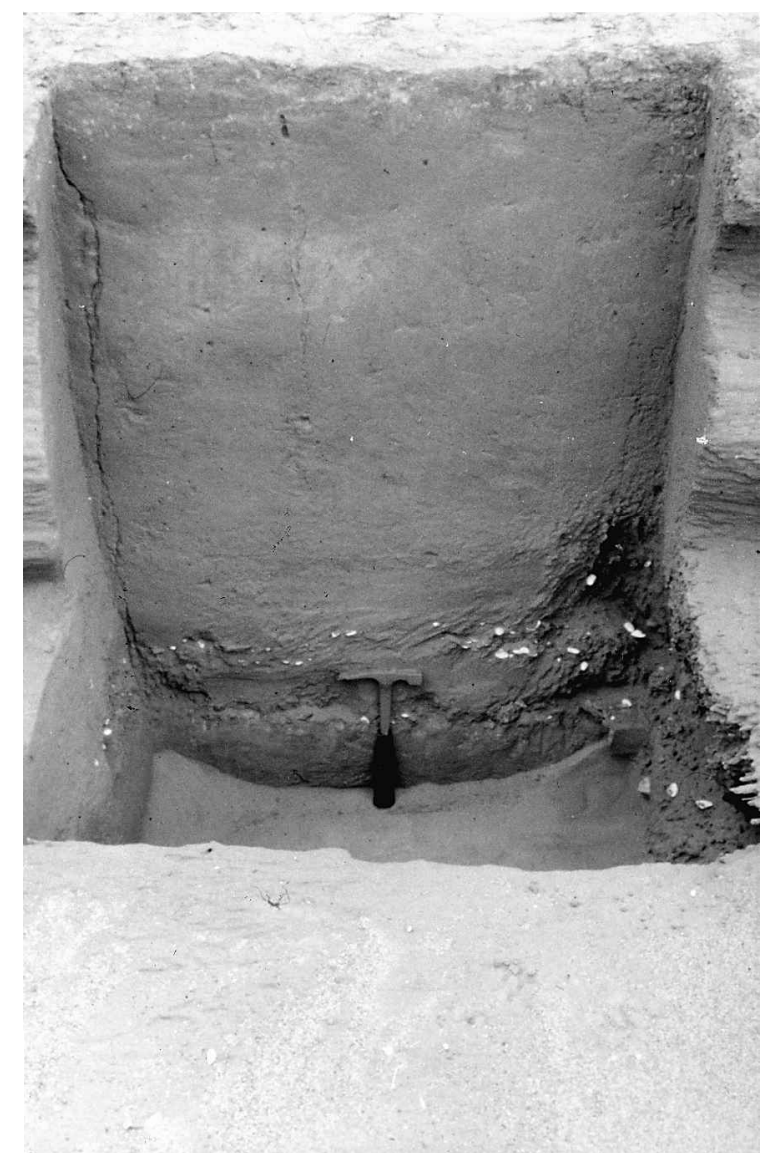

Figure 5 The pick marks a stratum of unconsolidated sand, silt, colluvial sediment and rock laid down by heavy flooding. The layer is buried in the desert plain near the Chimu site of Cañoncillo (c. AD 1300-1450).

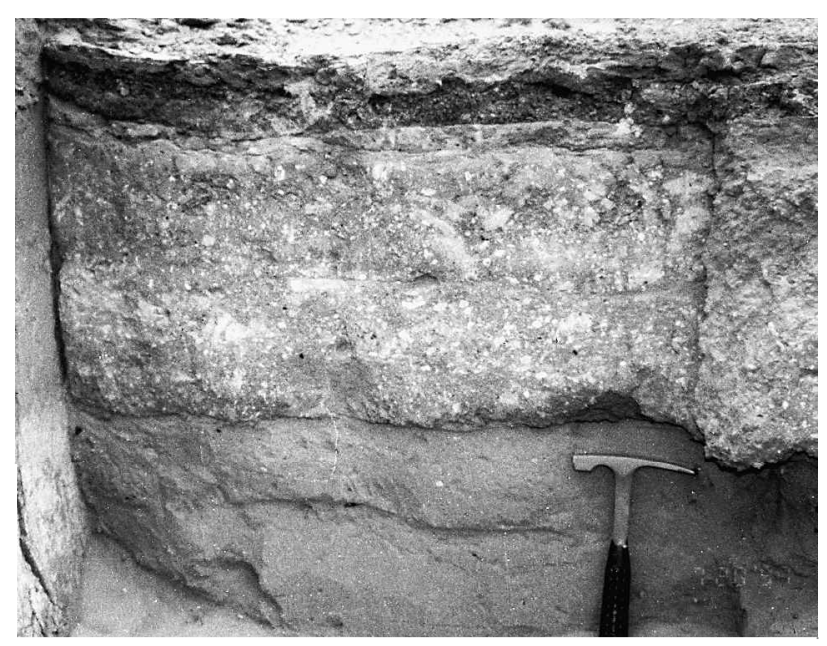

Figure 6 Archaeological cut showing a stratigraphic profile of an adobe wall (above the pick) of a residential structure built on top of a thick aeolian sand deposit in Cañoncillo.

interrupted occupational activity (Figure 6). At Farfan Sur, a single massive flood event is evidenced by thick outwash deposits that eroded and overlaid an adobe brick floor in a Chimu platform mound. The paved floor was immediately rebuilt after the flood. Radiocarbon dates derived from single chunks of charcoal embedded in the destroyed and rebuilt floors were statistically indistinguishable at $640 \pm 40 \mathrm{BP}(c$. AD 1310) and $620 \pm 40 \mathrm{BP}(c$. $\mathrm{AD}$ $1330)$, respectively, suggesting that the flooding and rebuilding episodes took place within a short timespan. Other major flood events in the valley are recorded in various house and platform floors and agricultural furrows in other Late Moche and Chimu sites (Table 2).

One long-term environmental effect of severe ENSO-related floods, and, to a lesser extent, light to moderate annual rainfall, stems from large quantities of entrained fluvial sediments deposited at the mouths of the Zana, Jequetepeque and Chicama rivers. Subsequently transformed into saltating sands, these sediments are driven inland by constant winds off the Pacific Ocean (Eling, 1987). Our geomorphological and archaeological surveys in the lower Zana and Jequetepeque rivers revealed stratigraphic deposits in the form of sand sheets and barchan dune formations that choked irrigation canals, buried old cultivation surfaces and covered residential structures. Extraordinary examples of massive dunefields are seen today on the desert plain from the Pacific Ocean to Cañoncillo and Quebrada de Cupisnique in zone 4 and across the plain from the Rio Seco to Cerro Huaca Blanca in zone 2 (Figures 2 and 7; see Eling, 1987). Most of these date to the Late Lambayeque and Chimu periods (AD 800-1470), as evidenced by associated diagnostic ceramics. In zones 2 and 3, our survey encountered hundreds of crescent-shaped, fieldstone windbreaks (Figure 8) built to inhibit the intrusion of saltating sands and massive dunes into agriculture fields and small domestic sites. In the Cañoncillo area, we also found extensive evidence of deforestation stemming from human activity and probably climatic change: stumps and roots of algarroba (Proposis sp.) trees exist on deflated, sand-inundated depressions where forests no longer exist. Deforestation itself increased likely erosion and deflation in these areas. Local exploitation of reduced, highly fragmented algarroba forests persists today.

Further, project geologist Mario Pino's research (personal communication, 2001) demonstrated heavily deflated surfaces and the presence of numerous yardangs dating from the Late Moche to Chimu periods, particularly in the Cañoncillo area (Eling, 1981; 1987). Geological cuts in several yardangs revealed complex interbedding of cultural and natural strata in the form of buried occupational surfaces, aeolian sand deposits, flood sediments and, in some localities, colluvial deposits. Several ${ }^{14} \mathrm{C}$ dates on charcoal extracted from yardangs (Eling, 1987), irrigation canals and deeply buried occupational surfaces indicate that the interaction between humans and the environment entailed numerous shortand long-term, sequential and convergent impact events interacting between $2800 \mathrm{BC}$ and the present. Excavated sediments in several localities reveal severe floods affecting the lower valley around AD 500-550 and then again around AD 1250.

\section{Variable human responses to major environmental events}

Excessive water from major ENSO floods has periodic and shortterm effects on cultural landscapes. In local settings where El Niño flooding was more severe, human responses were highly sophisticated and readily identifiable in the archaeological record. In several instances, defensive overflow weirs of the Chimu period were incorporated into massive aqueducts that bridged deep arroyos (see Eling, 1987). These weirs were designed to reduce the pressure of excessive flow rates and potential erosion in the aqueduct bed (Figure 9; C. Ortloff, personal communication, 2000). In addition, aqueduct foundations were constructed of large fieldstones that incorporated small diversion channels to further inhibit structural damage from high-flow precipitation events. We documented major rebuilding episodes of both Late Moche and Chimu canals, aqueducts and residential structures in stratigraphic excavations placed in Cañoncillo, Farfan, Talambo and several small and intermediate-scale Chimu sites in all zones. In these localities, rebuilt architecture directly overlaid thick outwash deposits. ${ }^{14} \mathrm{C}$ assays on wood charcoal excavated from basal strata 
Table 2 Radiocarbon dated events of major flooding at excavated archaeological sites in the lower Jequetepeque Valley

\begin{tabular}{|c|c|c|c|c|}
\hline Site number* & Context & Conventional age & Calibrated age & Sample no. \\
\hline JE-205\# & Occupation layer & $4190 \pm 40 \mathrm{BP}$ & $2895-2610$ вС & Beta-109092 \\
\hline JE-354 & Occupation layer & $2530 \pm 50 \mathrm{BP}$ & $805-485$ вС & Beta-109089 \\
\hline JE-205 & Occupation layer & $2520 \pm 50 \mathrm{BP}$ & $800-415$ вС & Beta-117746 \\
\hline JE-205 & Occupation layer & $2370 \pm 50 \mathrm{BP}$ & $530-375$ вс & Beta-117747 \\
\hline JE-339 & House floor & $1370 \pm 70 \mathrm{BP}$ & AD $560-780$ & Beta-143885 \\
\hline JE-273 & Platform floor & $770 \pm 50 \mathrm{BP}$ & AD 1185-1295 & Beta-143884 \\
\hline JE-1 & Platform floor & $720 \pm 40 \mathrm{BP}$ & AD $1180-1230$ & Beta-109093 \\
\hline JE-18 & House floor & $710 \pm 40 \mathrm{BP}$ & AD $1245-1390$ & Beta-109090 \\
\hline JE-2 & House floor & $700 \pm 60 \mathrm{BP}$ & AD $1235-1400$ & Beta-114185 \\
\hline JE-240 & Buried furrow & $670 \pm 70 \mathrm{BP}$ & AD $1245-1420$ & Beta-114186 \\
\hline JE-19 & House floor & $640 \pm 40 \mathrm{BP}$ & AD $1285-1405$ & Beta- 143880 \\
\hline JE-19 & Platform floor & $620 \pm 40 \mathrm{BP}$ & AD $1290-1410$ & Beta-143879 \\
\hline JE-619 & House floor & $620 \pm 50 \mathrm{BP}$ & AD $1280-1420$ & Beta-161940 \\
\hline JE-3 & House floor & $580 \pm 70 \mathrm{BP}$ & AD $1285-1445$ & Beta-143882 \\
\hline JE-688 & House floor & $230 \pm 40 \mathrm{BP}$ & AD $1640-1690$ & Beta-161941 \\
\hline JE-205 & Flood deposit & $180 \pm 50 \mathrm{BP}$ & AD $1650-1950$ & Beta-109092 \\
\hline
\end{tabular}

*All dates are single chunks of charcoal taken from intact strata with archaeological floors and/or features that lie either directly under or over major outwash deposits.

\#JE-205 corresponds to the urban centre of Cañoncillo.

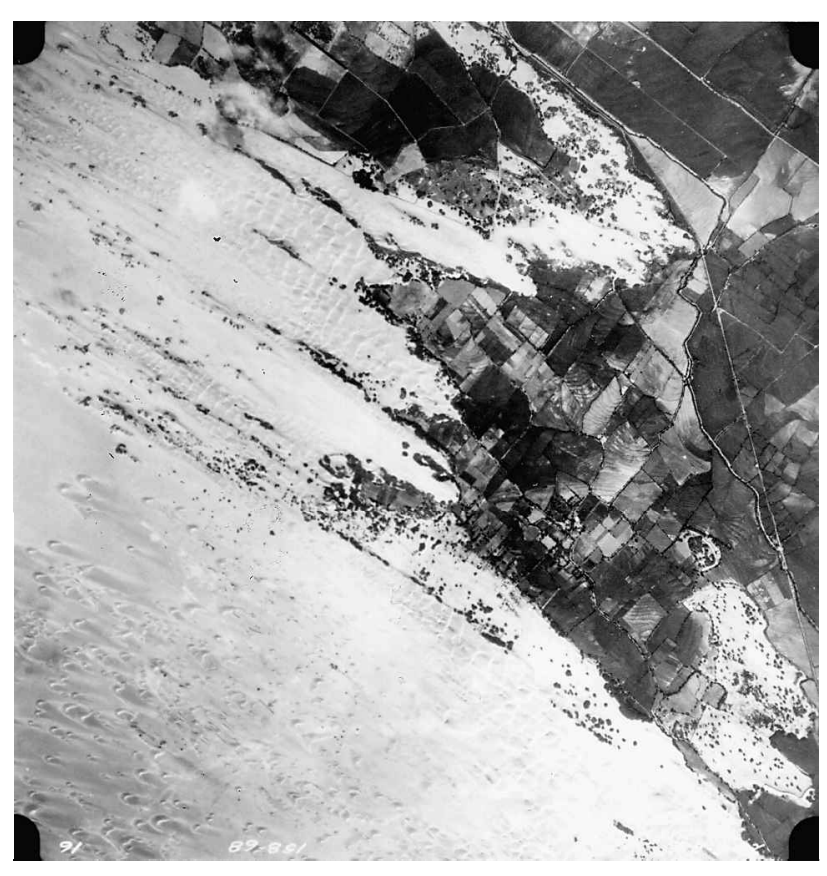

Figure 7 Aerial view of massive dunefields migrating into present-day agricultural land on the south side of the Jequetepeque Valley.

and floors associated with rebuilding episodes at the Chimu sites of Farfan Sur (AD 1245-1420, 1285-1405), Cañoncillo (AD 11201280 and AD 1650-1950), JE-2 (AD 1235-1400), JE-240 (AD 1245-1420) and JE-273 (AD 1185-1295) and at the late Moche sites of JE-1 (AD 1230-1270?) and JE-279 (AD 560-780) dated massive flood deposits. Earlier large-scale flood events were dated at 2895-2610, 840-520, 805-484, 800-415 and 530-375 вC at several Late Preceramic and Formative period sites in the lower valley. Although we have not focused our study on mid-Holocene archaeological sites (c. 5500-3000 BC), our radiocarbon dated chronological sequence of heavy debris-flow events in both

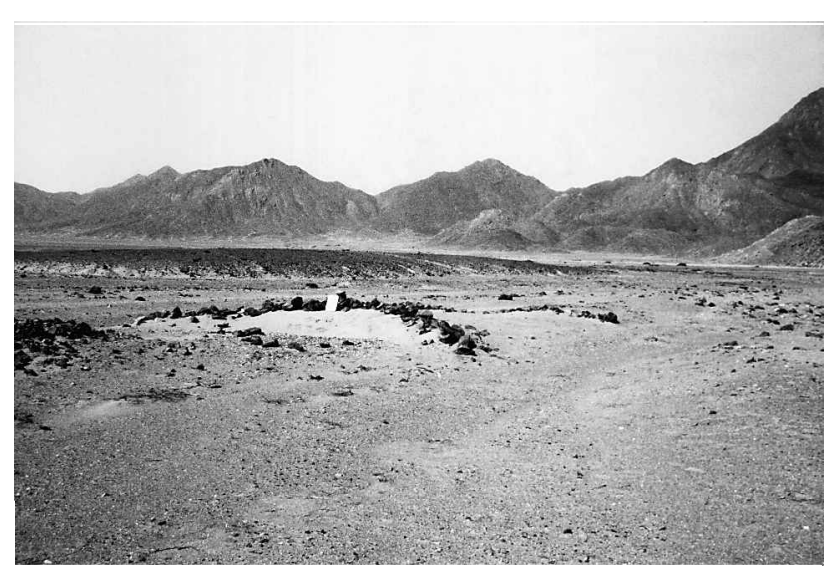

Figure 8 Chimu-built windbreakers or pircas deterring the movement of windblown sand into agricultural fields and residential sites near Cerro Huaca Blanca.

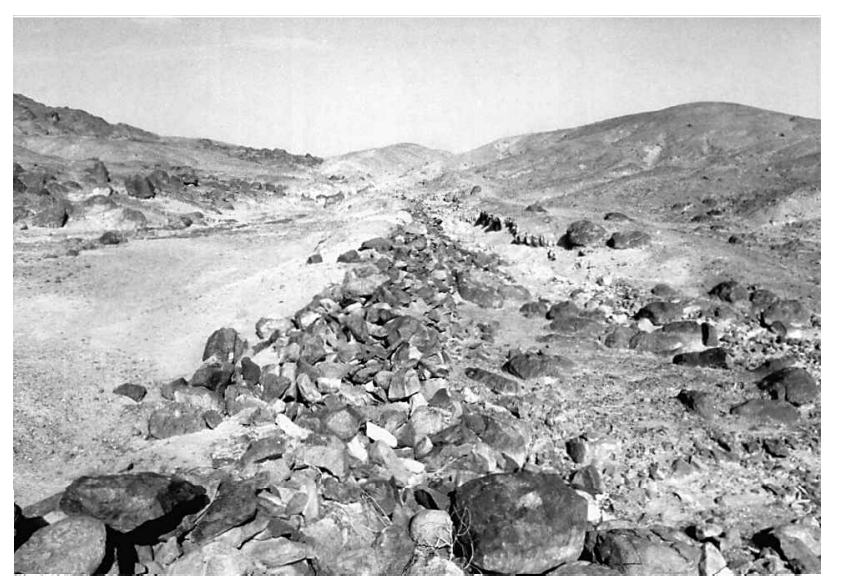

Figure 9 Large weir and break-wall associated with a massive aqueduct and designed to store water and to slow water to prevent erosion. 
geological and archaeological sites generally agrees with the findings of other projects along the coast of Peru, which have revealed an increase of ENSO events in the middle- to late-Holocene period (e.g., Rodbell et al., 1999; Wells, 1987; 1990; Sandweiss et al., 1996; Wells and Noller, 1997).

In some areas, outwash events associated with canals, agricultural fields, aqueducts and rural settlements served as temporal indicators, as well as indexing highly localized and differential land-use patterns by rural communities. These communities were evidently aware of the potential destructive impact of periodic flooding and apparently avoided severe damage by locating key settlements and agricultural infrastructure in areas less susceptible to rapid runoff, especially in the later Lambayeque and Chimu periods. For example, in small Lambayeque and Chimu sites located on gently inclined slopes of Cerro Santa Catalina in zone 2 wash deposits were absent or only $1-2 \mathrm{~cm}$ thick and often confined to nearby drainages, thereby having little impact on adjacent domestic areas. The later Chimu populations particularly avoided terrain highly vulnerable to flooding and dunation.

Chronic water shortages and fluctuations in the discharge volumes of coastal rivers represent a long-term environmental constraint on human occupation of the desert coast, especially in times of drought. Under normal conditions, water was a scarce commodity in the arid environment of the desert region of Peru. The archaeological evidence suggests that, in the absence of ENSO events and normal rainfall, coastal irrigation agriculture depended on precipitation in adjacent highlands basins. Any significant disruption of this pattern due to drought had rapid and widespread adverse effects on coastal populations during all cultural periods. Buried sand dunes and severely deflated surfaces in all zones provide indirect, but compelling, evidence of protracted drought conditions. Further, stratigraphic evidence at the Chimu sites of Cañoncillo and Talambo suggests that long-term desertification was interrupted periodically by severe, and in some instances catastrophic, flooding events that induced mass wasting of landscapes. Yet, prolonged drought may have been more detrimental to sustained agriculture than episodic ENSO flooding, as suggested by the widespread presence of multistratified palaeodunes that are interbedded with major, but intermittent, outwash deposits dating between approximately AD 1000 and 1450. Cultural responses to protracted droughts, even more than periodic ENSO-driven floods, required coordinated rural-urban reaction on a regional scale. Other responses entailed periodic abandonment of settlements and, perhaps in rarer cases, complete collapse of production systems (Dillehay, 2001), as has been documented during different cultural periods for the Moche Valley (Moseley, 1990) and the southern Lake Titicaca basin (Kolata, 1993a; 1993b; 1996; Ortloff and Kolata, 1993).

Rural farming communities responded to short-term drought through a variety of strategies such as reducing the intensity or extent of irrigation, changing the composition of cultigens, temporarily shifting production to heavier reliance on maritime or pastoral resources, and maximizing all water sources. Results of our excavations in Late Moche, Lambayeque and Chimu domestic sites (Dillehay and Rossen, 1987; 1988; Dillehay et al., 2001) reveal shifts in the frequency and type of floral and faunal species in stratigraphic thin floors that represent short-term episodes of habitation in rural villages. Although some shifts are probably linked to changing political and economic conditions, many appear to be the result of environmental events as suggested by the intermittent presence of thick aeolian and/or fluvial deposits directly overlaid by habitation floors containing changes in the frequency of marine shells and more drought-resistant crops such as peanuts, beans and maize.

Our data also show that rural inhabitants of the valley opportunistically expanded cultivation in the short term to take advantage of episodic, ENSO-driven rainfall. This is evidenced archaeolog-

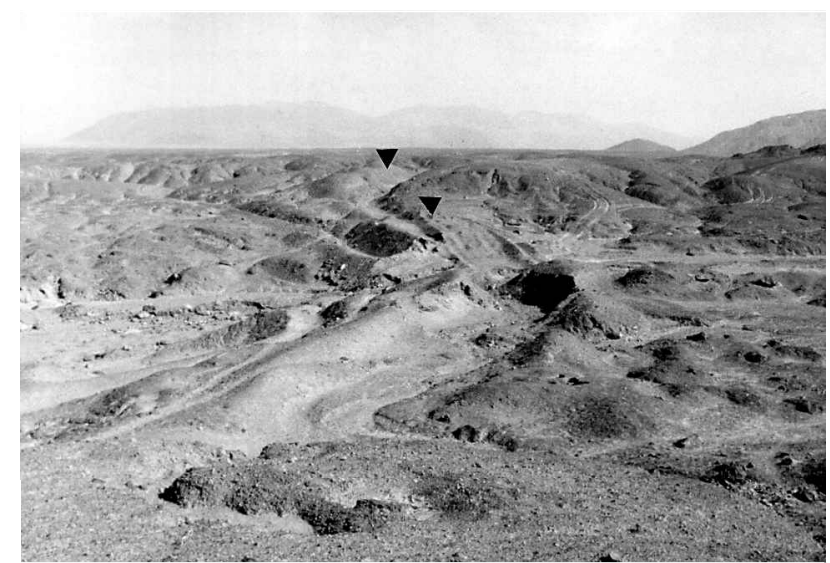

Figure 10 Massive aqueduct bridging an arroyo east of Pacatanamu (arrows point to canal, aqueduct and wash event).

ically by the presence of ephemeral homesteads and agricultural features located in isolated, low-lying desert areas where water accumulates during major flooding. As noted, these flood events deposit rich alluvium and recharge depleted groundwater tables, permitting at least temporary cultivation of previously non-arable lands. (Even today in the valley, local families practise opportunistic farming in low, humid areas during ENSO events.) Opportunistic farming of flood deposits combined with residential fluidity most likely enabled rural populations to sustain themselves in times of environmental crisis.

Another effective solution to water scarcity and distribution was construction of large aqueducts that bridged arroyos between Cerro Faclo and the desert plains east of Pacatnamu (Figure 10) and exploited remote water sources. Our survey confirmed much of Eling's $(1981 ; 1987)$ previous research on canal and aqueduct distributions, and discovered several other previously undocumented agricultural systems. Extensive areas of well-preserved agricultural fields with both linear and sinuous furrow patterns are found in all zones. Zones 2, 3 and 4 exhibit widespread practice of floodplain cultivation dating to the Late Moche through Chimu periods, particularly along seasonal or low-discharge drainages systems (Figure 11). Reuse, rebuilding and relocation of major canals also occurred in several localities with the largest canal associated with the Chimu urban site of Cañoncillo in zone 4. Canals in the lower valley were situated high and closely followed natural contours to maximize the area of irrigated fields. Several dispersed holding ponds and small reservoirs were located in hillsides above cultivated fields to enhance control of water use and distribution.

One other potential response to water scarcity was the culti-

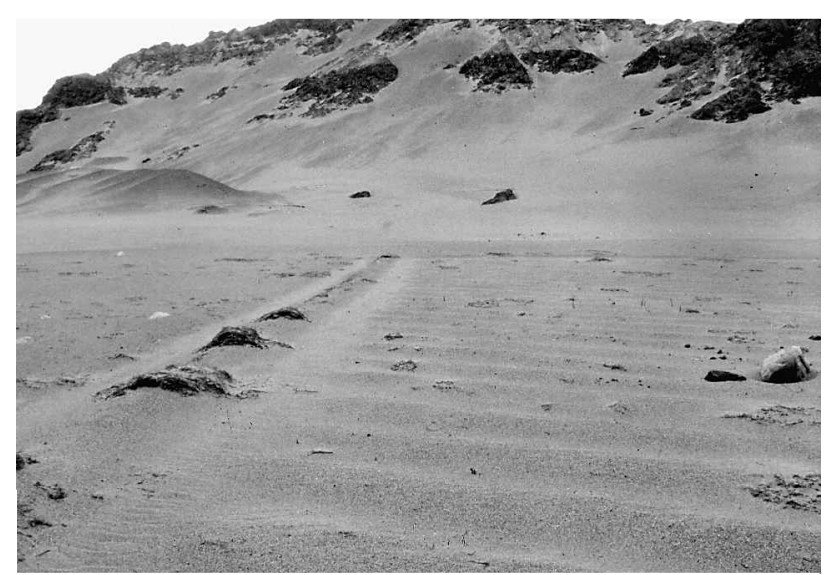

Figure 11 Chimu furrows located near Cerro Faclo between the large urban sites of Pacatanamu and Farfan Sur. 
vation of crop varieties resistant to aridity, and use of soil amendments (e.g., guano) to fertilize agricultural fields and to control the introduction of acidic soils on field surfaces. Soil-chemistry studies carried out on sediment samples collected from furrows and other agricultural features dating between Late Moche and Chimu times reveal moderately high amounts of zinc, calcium, phosphate, aluminium and potassium in comparison to control samples in offsite and non-agricultural areas (Soil Chemistry Laboratory, 2000), suggesting that guano and possibly other fertilizers were used to enhance soil nutrition.

Together severe ENSO events, dunation and droughts created a juxtaposed pattern of highly contrasting effects within the small region of the lower Jequetepeque Valley. Correlations between environmental perturbations and cultural patterning reveal variable combinations of economic opportunism and production activity that underlie the interactions of human populations during the Late Moche, Lambayeque and Chimu periods. Communities of all periods but especially in Lambayeque and Chimu times (c. AD 900-1400) responded to major ENSO events by relocating settlements in landscapes less susceptible to flooding or simply by repeatedly rebuilding damaged structures. The archaeological evidence suggests that, when natural resources were relatively predictable in space and time and not subjected to massive ecological degradation, urban settlements flourished in the Jequetepeque Valley, particularly in zones of high primary productivity, such as the expansive, alluvial floodplains or along littoral zones in zones 1 and 3 . When resources were depleted by gradual ecological degradation or by abrupt environmental change, the distribution and character of associated rural settlements and the nature of intensive production systems exhibit significant reorganization. For instance, we documented a shift to smaller, less densely inhabited and less specialized occupations in both urban and rural sectors during the Late Moche and Lambayeque periods ( $c$. AD 650-1000). The Chimu populations, on the other hand, reveal less mobility between settlements than the earlier Moche and Lambayeque people, perhaps because they had learned where to locate their cities and villages to lessen the negative impact of physical disasters, had concentrated more people in urban areas, and had greater political control over these populations.

Our settlement pattern studies also indicate that, rather than utilizing all available arable land, rural populations clustered in separate pockets often separated by tracts of unoccupied (potentially arable) lands. Although large urban settlements were geographically fixed localities subject to episodes of growth, recession and abandonment, people in the countryside during all cultural periods were highly mobile, and frequently moved from one part of the valley to another in response to changing conditions in the local sociopolitical and physical environment (Dillehay, 2001). Despite periodic episodes of environmental and political crises, many rural communities continued to survive, most likely through significant restructuring of social organization and intercommunity relations and through shifts in their domestic and political economies.

In sum, although the extent of physical damage from major environmental events is widespread throughout the study area, the severity of impacts was highly localized and varied significantly in effect, depending on local hydrology and topographic characteristics. Most events probably had extensive negative impacts on agricultural production and occasionally on the continuity of local political leadership residing in large urban areas. Human response to potential and actual environmental crises was also highly variable, ranging from preventive measures in locating settlements or engineering defensive components in agricultural infrastructures to repeated reconstruction of damaged structures. In some circumstances, formerly occupied or cultivated locales were simply abandoned in the face of mass wasting due to flooding or encroaching dune formation. Collectively, these data reflect an extraordinarily dynamic environment that generated repeated stress on local production systems. Such volatile environmental conditions placed a premium on prediction skills, technological innovation and social response capabilities of human populations. In particular, the capacity to mobilize human labour on a regional scale was essential to effective response efforts. Above all, recovery from drought and individual impact events, such as ENSO-driven flooding, demanded coordinated efforts to re-engineer or rebuild irrigation networks and associated hydraulic infrastructure, and to reconstruct destroyed domestic and ceremonial architecture.

Alternatively, resource depletion induced by environmental change probably stimulated increased competition, internal social conflict, warfare (Figure 12), predatory expansion and even imperialism among different polities in the region, especially during the period from $\mathrm{AD} 550$ to 1100 when numerous hilltop fortresses were scattered throughout the Jequetepeque and neighbouring valleys (Dillehay, 2001). Such social processes probably resulted in the mobilization of new resources under the patronage of more powerfully centralized authorities whose spatial and political reach, and therefore potential resource base, exceeded that of the local, incorporated polity. This seems to be the case with the Chimu state that dominated the valley from $c$. AD 1200 to 1450 . The subsequent Inca response to environmental and political stress repeated the Chimu pattern.

\section{Conclusion}

Detailed geological work and archaeological survey, excavation and stratigraphic evidence from urban and rural settlements distributed across the lower Jequetepeque Valley demonstrate that local human responses to major environmental impacts included: (1) periodic abandonment of agricultural systems and associated rural settlements; (2) restoration of damaged agricultural infrastructure and residential and administrative architecture; (3) construction of new canal and aqueduct systems; (4) community mobilization to remove intrusive sediments generated by episodic flooding or to construct physical barriers to prevent sand-dune encroachment; (5) shift in economic emphasis to non-agricultural activities, such as fishing and/or pastoralism; and (6) competitive warfare and conflict over access to productive resource zones. This spectrum of responses represents a diverse portfolio of human reaction to changing environmental regimes.

Understanding the problem of how pre-industrial urban-rural systems were sustained or failed in the context of interrelated social and environmental crises is an interdisciplinary objective, one that requires the analytical techniques and theoretical frameworks of both the natural and social sciences. With respect to our understanding of this problem in the pre-industrial Peruvian

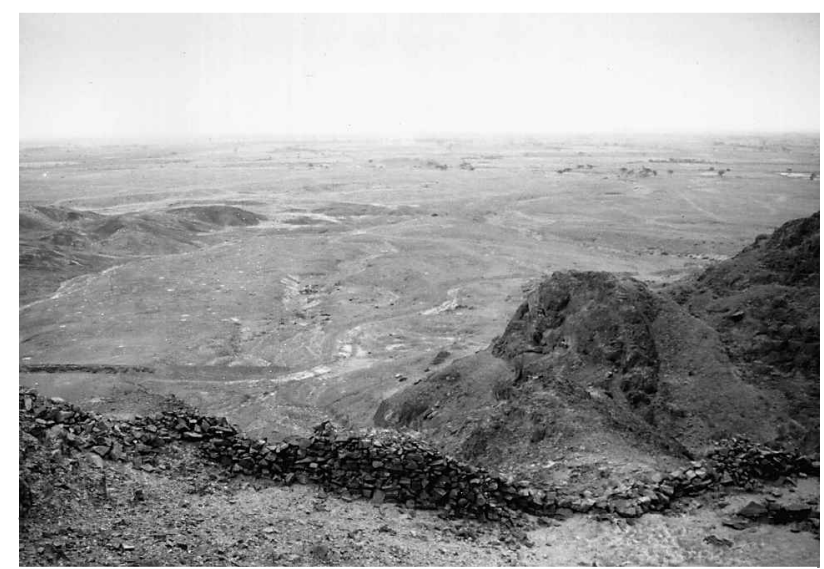

Figure 12 Hill defensive wall on hillside of site JE-125 (zone 1) overlooking the desert plain near Pacatnamu. 
context, our focus on palaeoenvironmental regimes, agricultural infrastructures and urban systems has enabled us to explore the complex interplay of sociocultural and natural forces that shaped the history of indigenous populations at high levels of integration as they faced periodic environmental disasters. Despite the great variety of potential outcomes in the interplay between these forces, the dominant trend emerging from our research in the Jequetepeque Valley is toward higher intensities of urbanization, increased population and more intensive patterns of land use up to the Inca period around AD 1450-1520, at which time the longlived indigenous urban system was effectively abandoned.

\section{Acknowledgements}

We wish to thank the Instituto Nacional de Cultura (INC) in Lima for granting us permission to carry out archaeological investigations in the Jequetepeque Valley. We also thank Cesar Galvez, Jesus Briceno and Ana Maria Hoyle of the INC in Trujillo for their co-operation. The National Science Foundation and National Geographic Society have generously supported portions of this project. We are grateful to many students who have worked with the project in recent years. Jeff Stvan produced Figure 2 and Jose Iriarte made Figure 4. We thank Herbert Eling for sharing his knowledge of the valley with us.

\section{References}

Bawden, G. 1996: The Moche. Cambridge: Blackwell Publishers. Bawden, G. and Reycraft, R., editors 2000: Confronting natural disaster: engaging the past to understand the future. Albuquerque: University of New Mexico Press.

Butterworth, D. and Chance, J., editors 1981: Latin American urbanization. Cambridge: Cambridge University Press.

Castillo, L.J. 1994: La Ocupación Moche de San Jose de Moro, Jequetepeque. In Uceda, S. and Mujica, E., editors, Moche: propuestas y perspectivas, Lima: Travaux de l'Institut Francais d'etudes Andines, 79, 93-146.

2001: The last of the Mochicas, a view from the Jequetepeque Valley. In Pillsbury, J., editor, Moche: art and political representation in ancient Peru, Washington, DC: National Gallery of Art, Center for the Advanced Study of Visual Arts, 143-79.

Conrad, G.W. 1990: Farfán, General Pacatnamú, and the dynastic history of Chimor. In Moseley, M.E. and Cordy-Collins, A., editors, The Northern Dynasties: kingship and statecraft in Chimor, Washington, DC: Dumbarton Oaks Research Library and Collection, 227-42.

Craig, A.K. and Shimada, I. 1986: El Niño flood deposits at Batán Grande, northern Peru. Geoarchaeology 1, 29-38.

Crumley, C. and Marquardt, W. 1990: Landscape: a unifying concept in regional analysis. In Allen, K., Green, S. and Zubrow, E., editors, Interpreting space: GIS and archaeology, London: Taylor and Francis, 73-79. Diaz, H. and Markgraf, V., editors, 1992: El Niño: historical and paleoclimatic aspects of the Southern Oscillation. Cambridge: Cambridge University Press.

Dillehay, T.D. 2001: Town and countryside in Late Moche times on the north coast. In Pillsbury, J., editor, Art and politics in Moche culture. Washington, DC: National Gallery of Art, 173-92.

Dillehay, T.D. and Rossen, J. 1987: Informe tecnico de la temporada arqueologica de 1987 en el Valle de Zaña, Perú. Technical report submitted to the Instituto Nacional de Cultura, Lima, Perú.

1988: Informe tecnico de la temporada arquelogica de 1988 en el Valle de Zaña, Perú. Technical report submitted to the Instituto Nacional de Cultura, Lima, Perú.

Dillehay, T.D., Kolata, A. and Swenson, E. 2001: Informe tecnico de la temporada arqueologica de 2001 en el Valle de Jequetepeque, Perú. Technical report submitted to the Instituto Nacional de Cultura, Lima, Perú.

Dillehay, T.D., Rossen, J. and Eling, H. 1989: Informe arqueológico de la campaña de 1992 en el Valle de Zaña. Lima: Instituto Nacional de Cultura, Lima, Perú.

Donnan, C.B. and Cock, G.A., editors, 1986: The Pacatnamú papers
Volume 1. Los Angeles: Museum of Cultural History, University of California.

- editors, 1997: The Pacatnamú papers. Volume 2. Los Angeles: Museum of Cultural History, University of California.

Eling, H. 1981: Prehispanic irrigation patterns: monadnocks of the Pampa de Mojucape, Jequetepeque Valley, Peru. Paper presented at the 4th Andean Archaeological Colloquium, University of California, Los Angeles, October.

1987: The role of irrigation networks in emerging societal complexity during late Prehispanic times, Jequetepeque Valley, north coast Peru. PhD dissertation, Department of Anthropology, University of Texas at Austin. Ann Arbor, MI: University Microfilms.

Fagan, B. 1999. Floods, famines, and emperors: El Niño and the fate of civilizations. New York: Basic Books.

Hecker, G. and Hecker, W. 1982: Pacatnamú: Vorspanische Stadt in Nordperu. Múnchen: C.H. Beck.

— 1991: Die Huaca 16 in Pacatnamú: Eine Ausgrabung an der Nordperuanischen Kuste. Berlin: D. Reimer.

Hecker, G., Hecker, W. and Ubbelohde-Doering, H. 1985: Pacatnamú y sus Construcciones: Centro Religioso Prehispánico en la Costa Norte Peruana. Frankfurt: Klaus Dieter Vervuert.

Hoffman, S.M. and A. Oliver-Smith, editors 2002: Catastrophe and culture: the anthropology of disaster. Santa Fe: School of American Research Press.

Hsu, J.F., Leonard, E.M. and Wehmiller, J.F. 1989: Amino-stratigraphy of Peruvian and Chilean Quaternary marine terraces. Quaternary Science Reviews 8, 255-62.

Keatinge, R.W. 1977: Religious forms and secular functions: the expansion of state bureaucracies as reflected in prehistoric architecture on the Peruvian north coast. Annals of the New York Academy of Sciences 293, 229-45.

1978: The Pacatnamú textiles. Archaeology 31(2), 30-41.

1982: The Chimú Empire in a regional perspective: cultural antecedents and continuities. In Moseley, M.E. and Day, K.C., editors, Chan Chan: Andean desert city, Albuquerque: University of New Mexico Press, 197-224.

Keatinge, R.W. and Conrad, G.W. 1983: Imperialist expansion in Peruvian prehistory: Chimú administration of a conquered territory. Journal of Field Archaeology 10(3), 255-83.

King, A. 1990: Urbanism, colonialism, and the world economy. London: Routledge.

Kolata, A.L. 1989: Introducción: objectivos y estrategias de la investigación. In Kolata, A.L., editor, Arqueología de Lukurmata. Volume 2, La Paz: Instituto Nacional de Arqueología y Ediciones Puma Punku, 13-40.

1990: The urban concept of Chan Chan. In Moseley, M.E. and Cordy-Collins, A., editors, The Northern Dynasties: kingship and statecraft in Chimor, Washington, DC: Dumbarton Oaks Research Library and Collection, 107-44.

- 1991: The technology and organization of agricultural production in the Tiwanaku State. Latin American Antiquity 2, 99-125.

- 1993a: The Tiwanaku: portrait of an Andean civilization. Oxford: Basil Blackwell.

- 1993b: Understanding Tiwanaku: conquest, colonization and clientage in the south central Andes. In Rice, D.S. and Stone, R., editors, Latin American horizons, Washington, DC: Dumbarton Oaks Research Library and Collection, 193-224.

— 1996: Tiwanaku and its hinterland: archaeology and paleoecology of an Andean civilization, volume 1: agroecology. Washington, DC: Smithsonian Institution Press.

2002: Tiwanaku and its hinterland: archaeology and paleoecology of an Andean civilization, volume 2: urban and rural archaeology. Washington, DC: Smithsonian Institution Press.

Kosok, Paul 1965: Life, land and water in ancient Peru. New York: Long Island University.

Morse, R. 1962: Latin American cities: aspects of function and structure. Comparative Studies in Society and History 4, 28-44.

Moseley, M.E. 1982: Introduction: human exploitation and organization on the north Andean coast. In Moseley, M.E. and Day, K.C., editors, Chan Chan: Andean desert city, Albuquerque: University of New Mexico Press, $1-24$.

- 1990: Structure and history in the dynastic lore of Chimor. In Moseley, M.E. and Cordy-Collins, A., editors, The Northern Dynasties: 
kingship and statecraft in Chimor, Washington, DC: Dumbarton Oaks Research Library and Collection, 1-41.

- 1992: The Incas and their ancestors: the archaeology of Peru. London: Thames and Hudson.

Moseley, M.E., Satterlee, D. and Richardson, J.B. III 1992: Flood events, El Niño events, and tectonic events. In Ortlieb, L. and Macharé, J. editors, Paleo-ENSO Records International Symposium Extended Abstracts, Lima: ORSTOM, 207-12.

Nials, F.L., Deeds, E., Moseley, M.E., Pozorski, S., Pozorski, T. and Feldman, R.A. 1979: El Niño: the catastrophic flooding of coastal Peru. Field Museum of Natural History Bulletin 50, 4-14 (Part I) and 4-10 (Part II).

Ortloff, C. and Kolata, A.L. 1993: Climate and collapse: agroecological perspectives on the decline of the Tiwanaku State. Journal of Archaeological Science 20, 195-221.

Philander, G. 1989: El Niño and La Niña. American Scientist 77, 451-59. Rodbell, D.T., Seltzer, G.O., Anderson, D.E., Abbott, M.B., Enfield, D.B. and Newman, J.H. 1999: A 15,000 year record of El Niño-driven alluviation in southwestern Ecuador. Science 283, 516-20.

Rossignol, J. and Wandsnider, L., editors, 1992: Space, time, and archaeological landscapes. New York: Plenum Press.

Salzgitter Industriebau GMBH 1968: Proyecto Jequetepeque: Estudio de la Primera Fase de Factibilidad Técnica y Economica Sobre el Proyecto de Irrigación del Valle de Jequetepeque (five volumes). Lima: Salzgitter Industriebau GMBH.

Sandweiss, D., Richardson, J., Reitz, E., Rollins, H. and Maasch, K. 1996: Geoarchaeological evidence from Peru for a 5000 year BP onset of El Niño. Science 273, 1531-33.

Shimada, I. 1978: Economy of a prehistoric urban context: commodity and labor flow at Moche V Pampa Grande, Peru. American Antiquity 43, 569-92.

— 1985: Perception, procurement, and management of resources: archaeological perspective. In Masuda, D., Shimada, I. and Morris, C., editors, Andean ecology and civilization, Tokyo: University of Tokyo Press, 357-99.
1990: Cultural continuities and discontinuities on the northern north Coast of Peru, middle-late horizons. In Moseley, M.E and Cordy-Collins, A., editors, The Northern Dynasties: kingship and statecraft in Chimor, Washington, DC: Dumbarton Oaks Research Library and Collection, 297-392.

1994: Pampa Grande and the Mochica Culture. Austin: University of Texas Press.

Shimada, I., Schaaf, C.B., Thompson, L.G. and Moseley-Thompson, E. 1991: Cultural impact of severe droughts in the prehistoric Andes: application of a 1500-year ice core precipitation record. World Archaeology 22, 247-70.

Soil Chemistry Laboratory 2000: Geochemical results of Jequetepeque samples. Lexington: University of Kentucky.

Stuiver, M., Reimer, P.J., Bard, E., Beck, J.W., Burr, G.S., Hughen, K.A., Kromer, B., McCormac, G., van der Plicht, J. and Spurk, M. 1998: INTCAL 98 radiocarbon age calibration. 24,000-0 cal. BP. Radiocarbon 40, 1041-83.

Tainter, J. 1989: The collapse of complex societies. Cambridge: Cambridge University Press.

Thompson, L.E., Bolzan, S.F. and Koci, B.R. 1985: A 1500-year record of tropical participation in ice cores from the Quelccaya Ice Cap, Peru. Science 229, 971-73.

Uceda, S. and Amico, J.C. 2093; Evidencias de grandes precipitaciones en diversas etapas constructivas de la Huaca de la Luna, costa norte del Perú. Boletin de Instituto Frances de Estudios Andinos 22(1), 313-43.

Weiss, H. and Bradley, R.S. 2001: What drives societal collapse? Science 291, 609-10.

Wells, L.E. 1987: An alluvial record of El Niño events from northern coastal Peru. Journal of Geophysical Research 92, 463-70.

1990: Holocene history of the El Niño phenomenon as recorded in flood sediments of northern coastal Peru. Geology 18, 1134-37.

Wells, L.E. and Noller, J.S. 1997: Determining the early history of El Niño. Science 276, 966.

Yoffee, N. and Cowgill, G.L., editors, 1988: The collapse of ancient states and civilizations. Tucson: University of Arizona Press. 
Copyright of Holocene is the property of Arnold Publishers and its content may not be copied or emailed to multiple sites or posted to a listserv without the copyright holder's express written permission. However, users may print, download, or email articles for individual use. 